\title{
Analisa Pengolahan Data Stasiun GPS CORS Gunung Merapi Menggunakan Perangkat Lunak Ilmiah GAMIT/GLOBK 10.6
}

\author{
Andri Arie Rahmad, Mokhamad Nur Cahyadi, Sulistiyani \\ Jurusan Teknik Geomatika, Fakultas Teknik Sipil dan Perencanaan, Institut Teknologi Sepuluh \\ Nopember (ITS) \\ Jl. Arief Rahman Hakim, Surabaya 60111 Indonesia \\ e-mail: cahyadi@geodesy.its.ac.id, sulistiyani@esdm.go.id
}

\begin{abstract}
Abstrak-Gunung Merapi merupakan salah satu gunung berapi yang paling aktif di Indonesia. Pemantauan aktivitas gunung berapi dapat dilakukan dengan berbagai metode salah satunya adalah metode deformasi. Pemantauan deformasi gunung berapi menggunakan Continously Operating Reference Stations (CORS) karena dapat menghasilkan data dengan ketelitian yang sangat tinggi hingga orde $\mathrm{mm}$ (milimeter). Untuk mendapatkan ketelitian yang tinggi, stasiun GPS CORS yang merupakan stasiun referensi GPS yang mengontrol GPS secara kontinu sangat bergantung pada berbagai macam faktor salah satunya strategi pengolahan data. Untuk memberikan gambaran tingkat ketelitian yang dihasilkan dari perangkat lunak pengolah GPS secara postprocessing, peneliti menggunakan perangkat lunak ilmiah GAMIT/GLOBK 10.6 yang diolah menggunakan dua metode konfigurasi jaring yaitu metode jaring tertutup dan metode radial. Dari hasil analisa yang dilakukan pada bulan Juli 2015, pengolahan data GPS CORS Gunung Merapi dengan GAMIT/GLOBK 10.6 memberikan tingkat hasil pengolahan data yang presisi sampai orde milimeter. Rata-rata nilai standar deviasi hasil pengolahan GAMIT/GLOBK metode jaring adalah $2,92 \mathrm{~mm}$ sedangkan pada metode radial adalah $3,39 \mathrm{~mm}$. Dari uji statistik metode jaring tertutup dan radial tidak terdapat perbedaan yang signifikan. Selisih rata-rata standar deviasi pada pengolahan GAMIT/GLOBK antara metode jaring tertutup dan radial adalah $0,47 \mathrm{~mm}$.
\end{abstract}

Kata Kunci-GAMIT/GLOBK, GPS CORS, Jaring Tertutup, Radial

\section{PENDAHULUAN}

$\mathrm{C}$ ORS (Continously Operating Reference Stations) merupakan sistem GNSS yang beroperasi secara kontinyu selama 24 jam sebagai acuan penentuan posisi dengan tingkat ketelitian yang tinggi. Pada saat ini pengguna teknologi CORS yang ada di Indonesia cukup banyak. Hal ini didukung dengan salah satu manfaat dari GPS CORS yang dapat digunakan dalam survei deformasi. Fenomena deformasi diantaranya adalah fenomena alam aktivitas gunung api.

Salah satu pemantauan gunung api menggunakan GPS CORS terletak pada jaringan stasiun GPS CORS Gunung Merapi. Gunung api yang memiliki ketinggian 2,968 m dpl (per 2006) ini merupakan salah satu gunung api di Pulau Jawa yang masih aktif sampai saat ini [1]. Dengan adanya pemantauan deformasi menggunakan GPS CORS dapat diperoleh informasi mengenai pergeseran suatu titik tanah sehingga dapat diketahui gejala- gejala vulkanik Gunung Merapi. Informasi yang didapatkan menjadi langkah awal dalam upaya mitigasi bencana Gunung Merapi. Pemantauan deformasi dengan GPS tidak pernah lepas dari perubahan koordinat beberapa titik yang mewakili sebuah gunung api dari waktu ke waktu. Untuk itu diperlukan data dengan ketelitian yang tinggi [2].

Salah satu faktor yang mempengaruhi ketelitian survei GPS ditentukan oleh beberapa faktor, salah satunya adalah pengolahan data. Pengolahan data GPS dimaksudkan untuk menghitung koordinat titik-titik dalam suatu jaring berdasarkan data-data pengamatan fase sinyal GPS yang diamati pada titiktitik pengamat [3]. Pengolahan data dilakukan dalam dua tahap, yaitu: pengolahan baseline yang bertujuan untuk menghasilkan komponen vektor baseline $(\Delta \mathrm{X}, \Delta \mathrm{Y}, \Delta \mathrm{Z})$ dan perataan jaring untuk mendapatkan koordinat dan ketelitian titik menggunakan komponen dari vektor baseline tersebut [4].

Pengolahan data GPS pada prinsipnya ada dua jenis perangkat lunak (software) yang dapat digunakan, yaitu perangkat lunak komersil serta perangkat lunak ilmiah. Perangkat lunak ilmiah umumnya digunakan untuk mengolah data survei geodesi yang menuntut ketelitian relatif lebih tinggi, dan memiliki cakupan jaringan yang umumnya berskala regional atau bahkan global [5].

Dengan dilakukan pengolahan data GPS Gunung Merapi menggunakan perangkat lunak ilmiah diharapkan dapat memberikan tingkat ketelitian hasil pengolahan secara postprocessing sebagai acuan dalam mengaplikasikan data GPS yang menuntut ketelitian yang tinggi (sampai orde milimeter), seperti untuk pengadaan titik-titik kontrol pemantauan Gunung Merapi, pemantauan deformasi, dan studi geodinamika.

\section{URAIAN PENELITIAN}

\section{A. Lokasi Penelitian}

Lokasi penelitian terletak pada jaringan stasiun pemantauan GPS CORS yang berapa pada kawasan Gunung Merapi, Daerah Istimewa Yogyakarta dan Jawa Tengah. Area studi ini terletak di posisi geografis lintang 7032'5" LS dan bujur 110'26'5” BT.

\section{B. Data dan Peralatan}

Data pengamatan GPS yang digunakan adalah data RINEX pada bulan Juli tahun 2015 (doy 182-212). Data tersimpan setiap 
jam dalam format RINEX dengan sampling pengukuran tiap 1 detik. Data pengamatan GPS diunduh di Balai Penyelidikan dan Pengembangan Teknologi Kebencanaan (BPPTKG) Yogyakarta. Data pengamatan GPS yang digunakan adalah GPS BPTK, GPS DELS, GPS GRWH, GPS KLAT.

Tabel 1.

Lokasi data pengamatan stasiun GPS CORS Merapi

\begin{tabular}{ccc}
\hline \hline No & Stasiun & Lokasi \\
\hline $\mathbf{1}$ & BPTK & Kantor Pusat, BPPTKG \\
$\mathbf{2}$ & DELS & Desa Deles, Klaten \\
$\mathbf{3}$ & GRWH & Desa Grawah, Boyolali \\
$\mathbf{4}$ & KLAT & Desa Klatakan, Magelang \\
\hline
\end{tabular}

Data sekunder dalam pengolahan GPS terdiri dari file Navigation Message Broadcast (brdc), file Satellite precise Ephemeris (sp3) yang dapat diunduh secara otomatis melalui software GAMIT/GLOBK atau ftp://cddis.gsfc.nasa.gov.

Ada 3 file tambahan yaitu: file atmosfer (atmdisp_YYYY), file gelombang pasang surut (otl_FES2004.grd), file pemodelan cuaca (vmf1grd.YYYY) yang dapat diunduh melalui ftp://everest.mit.edu/pub/GRIDS/.

Peralatan yang digunakan dalam penelitian ini terdiri dari perangkat keras dan perangkat lunak. Perangkat keras yang digunakan antara lain: GPS Receiver Leica GR 10, Antena GPS Leica AR 10, dan personal computer sebagai alat pengolah data GPS.

Perangkat lunak yang digunakan antara lain: sistem operasi Windows 7 dan Linux Ubuntu 15.04, GAMIT dan GLOBK 10.6 sebagai perangkat lunak ilmiah, GMT (Generic Mapping Tools) 5.1.1 digunakan untuk plotting hasil pengolahan GAMIT, TEQC digunakan untuk penggabungan data RINEX, Matlab R2010a digunakan untuk transformasi koordinat ke sistem toposentrik, dan Microsoft Excel digunakan untuk pengolahan hasil tabular koordinat dari GAMIT.

\section{Diagram Alir Penelitian}

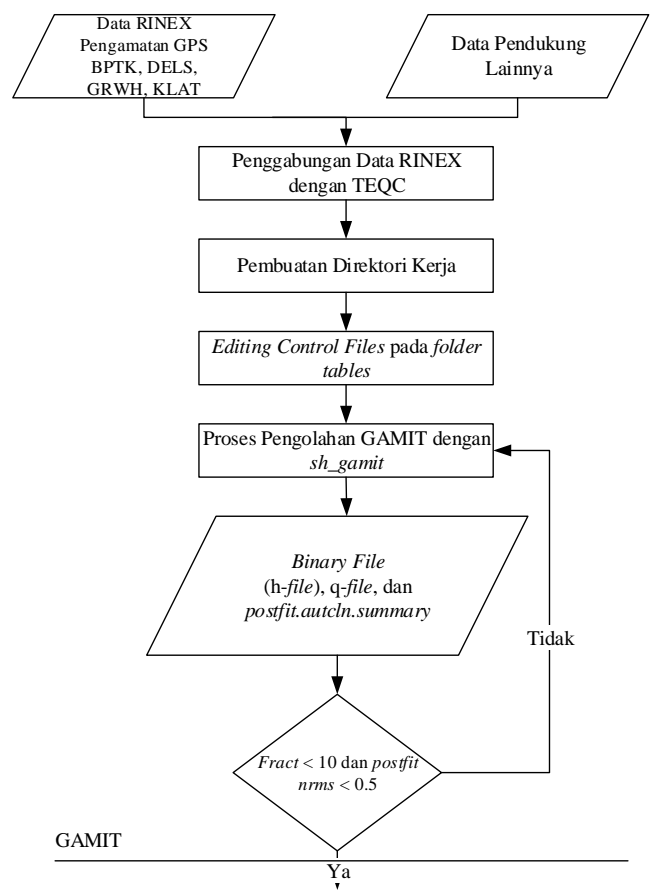

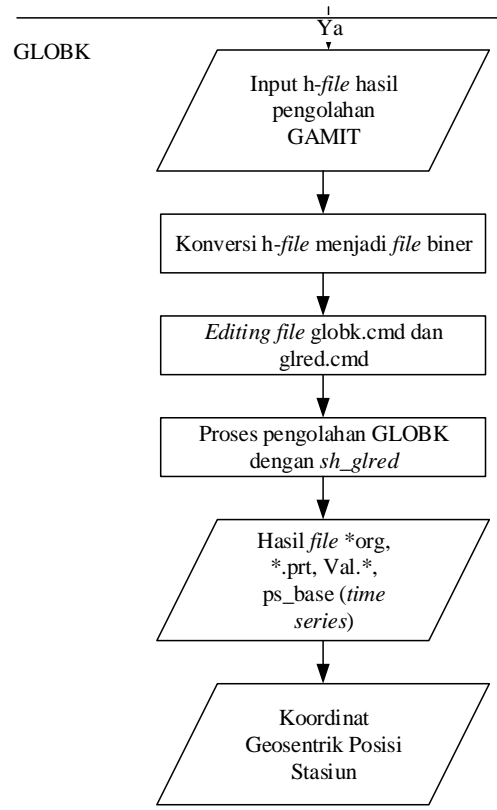

Gambar 1. Diagram alir pengolahan GAMIT/GLOBK 10.6

Berikut ini adalah penjelasan pengolahan data GPS dengan GAMIT/GLOBK 10.6:

1. Data RINEX pengamatan GPS yang digunakan adalah BPTK, DELS, GRWH, dan KLAT pada bulan Juli 2015.

2. Data RINEX tersimpan dalam setiap jam dilakukan penggabungan data RINEX menjadi 1 hari dengan perangkat lunak TEQC agar bisa diolah dalam perangkat lunak GAMIT/GLOBK. Proses menjalankan perangkat lunak TEQC dilakukan melalui command prompt, file RINEX diletakkan dalam satu direktori dengan software teqc.exe.

3. Pembuatan direktori kerja

Pengolahan data dengan GAMIT diperlukan pembuatan direktori kerja yang dibuat di dalam masing-masing direktori project yang digunakan. Project tersebut berisi folder-folder berikut ini:

a. rinex, folder yang digunakan untuk menyimpan file-file RINEX observasi pengamatan dan titik kontrol.

b. igs, folder yang digunakan untuk menyimpan file final IGS precise ephemeris dengan format *.sp3.

c. $b r d c$, folder yang digunakan untuk menyimpan file navigasi global sesuai dengan doy project yang akan diolah.

d. Tables, folder yang berisi file-file kontrol dari pengolahan GAMIT. Folder tables dibuat secara otomatis menggunakan perintah bawaan dari perangkat lunak GAMIT.

4. Pengaturan control files pada folder tables

Control files pada folder tables merupakan link dari folder tables pada perangkat lunak GAMIT/GLOBK dengan menjalankan perintah:

\begin{tabular}{|c|}
\hline sh_setup -yr 2015 -apr itrf08.apr \\
Pengaturan control files yang dilakukan adalah
\end{tabular}

a. File lfile, berisi koordinat pendekatan (apriori) dari stasiun pengamatan global. Koordinat dari stasiun BPTK, DELS, GRWH, KLAT didapatkan data apriori dari masing-masing RINEX-nya.

b. File station.info, berisi informasi tentang stasiun titik yang diolah. Informasi tersebut diantaranya adalah informasi 
waktu (session start dan session stop) yang menunjukkan waktu mulai dan berhentinya pengukuran, antenna type, dan receiver type.

c. File sites.defaults, merupakan file yang digunakan untuk mengontrol penggunaan stasiun dalam pengolahan GAMIT dan GLOBK. Pengisian file ini diisi dengan nama stasiun (site), nama project yang digunakan (expt), dan opsi lainnya (seperti: localrx dan xstinfo).

d. File sestbl, merupakan file yang digunakan dalam proses pengolahan. Choice of experiment yang digunakan adalah opsi "BASELINE". Bagian lain yang diedit adalah atml.grid sebagai kandungan atmosfer pilih opsi "Y", map.grid sebagai pengeplotan koordinat repeatabilities dengan GMT pilih opsi "Y", serta otl.grid sebagai pemodelan pasang surut air laut pilih opsi "Y". Bagian lainnya tidak perlu diubah dan mengikuti nilai yang diberikan oleh GAMIT.

e. File sittbl, merupakan file yang digunakan untuk memasukkan nilai constraint dari setiap stasiun yang diolah oleh GAMIT. File ini sudah berisi nilai constraint untuk stasiun global yang dapat digunakan sebagai titik kontrol. Nilai setiap titik berbeda besarannya, tergantung fungsi dari titik tersebut sebagai titik pengamatan atau sebagai titik kontrol. Nilai constraint kecil mendekati nol mengakibatkan nilai bobotnya besar (asumsi stasiun stabil). Sedangkan nilai constraint besar mendekati 100, mengakibatkan nilai bobot menjadi kecil (asumsi stasiun tidak stabil).

f. File process.defaults, merupakan file yang digunakan untuk menentukan lokasi direktori yang digunakan pada project yang sedang dijalankan. File ini juga digunakan untuk menentukan file navigasi yang digunakan serta apr file yang digunakan pada GLOBK.

5. Pengolahan menggunakan GAMIT

Perintah untuk menjalankan proses pengolahan GAMIT dengan automatic batch processing pada direktori kerja sebagai berikut:

sh_gamit -s yyyy ddd 1 ddd 2 -expt <expt> -nogifs y

6. File hasil yang didapat dari pengolahan GAMIT adalah folder sebanyak doy yang diolah. Setiap folder doy menghasilkan beberapa file yaitu: q-file, h-file, dan sh_gamit.summary. Selanjutnya dilakukan evaluasi terhadap hasil pengolahan dengan membuka q-file seri "a" pada setiap folderldoy dengan kriteria sebagai berikut [6]:

a. Solusi harian yang baik menghasilkan normalized root mean square harus kurang dari 0,3 .

b. Solusi bagian fract masing-masing titik pada masing-masing komponen harus kurang dari 10.

Setelah evaluasi pengolahan GAMIT sudah memenuhi nilai yang ditetapkan, dilanjutkan dengan proses pengolahan dengan GLOBK.

7. Input $h$-file hasil pengolahan GAMIT dan $h$-file global dalam masing-masing sebuah folder dan konversi $h$-file tersebut ke dalam format biner. Keluaran dalam bentuk biner akan berformat *.glx (solusi bias-fixed) dan *.glr (solusi bias-free). Data biner format *.glx yang dipakai dalam pengolahan GLOBK. File berformat *.glx perlu digabungkan menjadi satu file dengan format *.gdl.

8. Editing file globk_cmd dan glorg_cmd.

Sebelum masuk ke pengolahan GLOBK, hal yang dilakukan adalah editing file globk_comb.cmd dan glorg_comb.cmd, yang dapat disalin dari folder /gg/tables, kemudian file tersebut ditempatkan di folder gsoln pada project yang akan diolah. Pada bagian prt_opt dan opt_prt tambahkan opsi BLEN dan UTM untuk mendapatkan panjang baseline dan output koordinat UTM.

9. Pengolahan menggunakan GLOBK

Selanjutnya menjalankan pengolahan GLOBK untuk perhitungan dan plotting coordinate repeatabilities secara time series dengan perintah sebagai berikut.

sh_glred -s yyyy1 ddd1 yyyy2 ddd2 -expt <expt> -opt H G E

10. Hasil dari pengolahan GLOBK adalah file VAL. 〈expt>, plotting time series (ps_base), print-files (*.prt) yang berisi solusi loosely constraint dari GLOBK, dan org-files (*.org) yang berisi koordinat toposentrik (north, east, up) dan koordinat geosentrik $(\mathrm{X}, \mathrm{Y}, \mathrm{Z})$ beserta standar deviasi setiap stasiunnya.

\section{HASIL DAN ANALISA}

\section{A. Hasil Pengolahan Data GPS dengan GAMIT/GLOBK}

Pada pengolahan dengan GAMIT/GLOBK dilakukan dua metode pengolahan, yaitu:

a. Metode jaring tertutup, dimana titik pengamatan per-doy diikatkan pada base stasiun BPTK yang berlokasi di kantor BPPTKG Yogyakarta.

b. Metode radial, dimana masing-masing titik pengamatan diikatkan pada base stasiun BPTK (per-baseline) yang berlokasi di kantor BPPTKG Yogyakarta.

Hasil yang didapat dari pengolahan GAMIT adalah folder sebanyak doy yang diolah. Setiap folder doy terdapat $\mathrm{h}$-file hasil pengolahan GAMIT yang memiliki nama dengan pola $\mathrm{h}$ [expt]a.yyddd, dimana [expt] adalah nama experiment, yy adalah dua angka terakhir pada tahun, dan ddd adalah doy dari data yang diolah. File $h$-file merupakan file yang memuat nilai adjustment dan matriks varian-kovarian. Selain $h$-file, hasil pengolahan GAMIT adalah $q$-file dimana memuat hasil analisa program solve yang berisi hasil evaluasi pengolahan data serta sh_gamit.summary untuk mengetahui informasi pengolahan GAMIT.

Evaluasi hasil pengolahan GAMIT menggunakan indikator nilai fract pada q-file versi "a". Nilai fract di atas 10 mengindikasikan ada kesalahan kasar dan sistematik pada proses pengolahan tersebut [7]. Fract merupakan hasil perbandingan antara nilai adjust dan nilai formal. Nilai adjust adalah besarnya perataan yang diberikan pada tiap stasiun. Sedangkan nilai formal menunjukkan ketidakpastian pada pemberian bobot untuk perhitungan kuadrat terkecil. Nilai fract di atas 10 terdapat pada stasiun DELS pada pengolahan metode radial yaitu doy 198 (longitude) sebesar 17,1 dan nilai terkecil juga terdapat pada stasiun DELS metode radial yaitu doy 198 (latitude) sebesar -13,8. Sedangkan pengolahan pada metode jaring nilai fract pada seluruh stasiun berada pada nilai di bawah 10.

Evaluasi lainnya dapat menggunakan indikator besaran nilai postfit nrms yang terdapat pada sh_gamit_dd.summary. Postfit nrms adalah merupakan perbandingan antara nilai akar kuadrat chi-square dan nilai derajat kebebasan. Solusi harian yang baik 
menghasilkan normalized root mean square harus kurang dari 0,3 . Jika lebih besar dari 0,5 maka mengindikasikan adanya masalah seperti cycle-slip yang tidak bisa dihilangkan atau stasiun fixed dengan koordinat yang jelek [6]. Nilai postfit tidak memiliki satuan. Nilai rata-rata postfit nrms dapat dilihat pada tabel 3. Pada tabel 3 nilai rata-rata postfit nrms memenuhi evaluasi solusi harian dan dapat dikategorikan baik.

Tabel 2.

Rata rata nilai postfit nrms pengolahan GAMIT

\begin{tabular}{cccc}
\hline \hline \multirow{2}{*}{ Jaring } & \multicolumn{3}{c}{ Radial } \\
\cline { 2 - 4 } 0,24849 & DELS-BPTK & GRWH-BPTK & KLAT-BPTK \\
\hline \hline
\end{tabular}

Parameter evaluasi lainnya yaitu nilai ambiguitas fase yang terdapat pada file sh_gamit.summary. Nilai wide lane (WL) adalah resolusi ambiguitas fase yang didapat dengan mengkombinasikan sinyal GPS L1 dikurangkan dengan GPS L2. Nilai WL pada GAMIT dikatakan tidak memiliki noise pada pseudorange jika resolusi ambiguitas fase WL-nya adalah melebihi $90 \%$. Sedangkan narrow lane (NL) adalah resolusi ambiguitas fase dengan mengkombinasikan sinyal GPS L1 ditambahkan dengan GPS L2. Nilai NL melebihi $80 \%$ pada resolusi ambiguitas fase NL-nya dikatakan tidak terdapat kesalahan pada ukuran, konfigurasi jaringan, kualitas orbit, koordinat apriori, atau kondisi atmosfer [6]. Proses kombinasi linier data fase GPS (wide lane dan narrow lane) berfungsi untuk mengubah besarnya efek kesalahan dan bias yang besarnya tergantung pada frekuensi sinyal, seperti bias karena refraksi ionosfer, noise dari pengamatan serta multipath. Sedangkan besarnya efek kesalahan dan bias yang besarnya tidak tergantung frekuensi sinyal, seperti kesalahan ephemeris, kesalahan dan offset jam GPS receiver maupun satelit, dan bias karena refraksi troposfer, akan tetap sama baik untuk sinyal kombinasi linier maupun untuk sinyal L1 dan L2 [2]. Gambar 2 menunjukkan nilai WL setiap doy sepanjang waktu observasi.

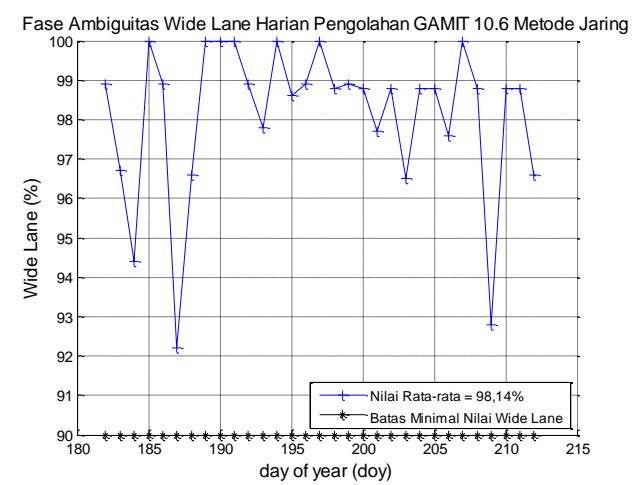

Gambar 2. Resolusi fase ambiguitas wide lane sepanjang hari pengamatan

Pada gambar 4.3 ditunjukkan bahwa nilai WL maksimal adalah $100 \%$, nilai minimalnya adalah $92,20 \%$ dengan nilai reratanya adalah $98,14 \%$. Hal ini menunjukkan bahwa hasil pengolahan data metode jaring dengan perangkat lunak GAMIT pada penelitian ini menggambarkan data GPS yang digunakan tidak memiliki noise pada pseudorange.

Sedangkan pada gambar 4.4 menunjukkan nilai NL setiap doy sepanjang waktu observasi. Nilai NL maksimal adalah $87,80 \%$, nilai minimalnya adalah $53,50 \%$ dengan nilai reratanya adalah
$76,27 \%$. Hal ini menunjukkan bahwa beberapa doy observasi kemungkinan terdapat kesalahan pada ukuran, konfigurasi jaringan, kualitas orbit, koordinat apriori, atau kondisi atmosfer [6].

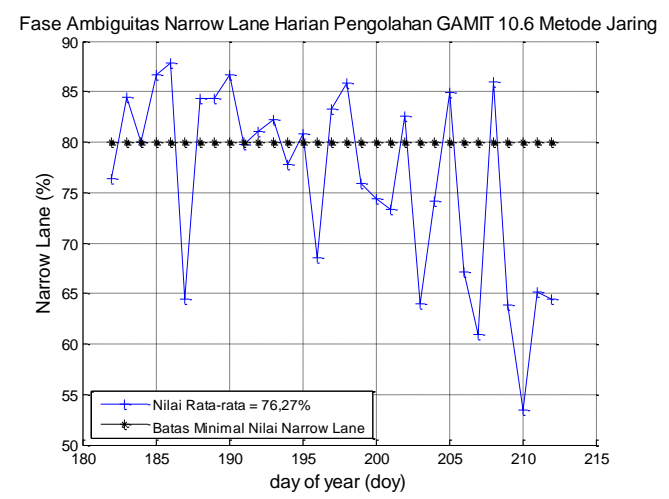

Gambar 3. Resolusi fase ambiguitas narrow lane sepanjang hari pengamatan

Pada metode radial dilakukan 3 kali pengolahan dengan GAMIT sehingga menghasilkan nilai wide lane dan narrow lane yang berbeda sesuai dengan pengolahan data GPS stasiun yang digunakan yang diikatkan pada titik ikat BPTK. Nilai ratarata wide lane dan narrow lane pada metode radial ditampilkan pada tabel 3 sebagai berikut.

Tabel 3.

Rata rata nilai wide lane dan narrow lane pengolahan GAMIT metode radial

\begin{tabular}{cccccc}
\hline \hline \multicolumn{2}{c}{ DELS-BPTK } & \multicolumn{2}{c}{ GRWH-BPTK } & \multicolumn{2}{c}{ KLAT-BPTK } \\
\hline Wide & Narrow & Wide & Narrow & Wide & Narrow \\
Lane & Lane & Lane & Lane & Lane & Lane \\
\hline $98,24 \%$ & $59,09 \%$ & $95,99 \%$ & $62,31 \%$ & $99,34 \%$ & $97,68 \%$ \\
\hline \hline
\end{tabular}

Ditunjukkan pada tabel 3 bahwa nilai wide lane pada seluruh pengolahan memenuhi resolusi ambiguitas fase hasil pengolahan harian yaitu berada di atas $90 \%$ yang menunjukkan bahwa tidak adanya noise pada pseudorange pada data GPS yang digunakan. Sedangkan nilai narrow lane pada pengolahan DELS-BPTK dan GRWH-BPTK masih di bawah nilai ketentuan $80 \%$. Hal ini menunjukkan pengolahan data masih terdapat kesalahan di data DELS dan GRWH sehingga akan mempengaruhi nilai narrow lane secara keseluruhan jika semua data GPS diolah secara bersamaan seperti pada metode jaring.

Setelah evaluasi pengolahan GAMIT sudah memenuhi nilai yang ditetapkan, dilanjutkan dengan proses pengolahan dengan GLOBK. Hasil dari pengolahan GLOBK adalah plotting time series dan nilai koordinat geosentrik $(\mathrm{X}, \mathrm{Y}, \mathrm{Z})$ dan koordinat lokal dalam northing $(\mathrm{N})$, easting $(\mathrm{E})$, dan up (U) beserta standar deviasi (sigma) pada file org-file yang memiliki nama dengan pola globk_[expt]_yyddd.org dimana [expt] adalah nama experiment, yy adalah dua angka terakhir pada tahun, dan ddd adalah doy dari data yang diolah. Pada tabel 4 menunjukkan perbedaan koordinat metode jaring dan radial pengolahan GAMIT/GLOBK mempunyai perbedaan fraksi sentimeter sampai milimeter. 
Tabel 4.

Rata rata koordinat geosentrik pengolahan data GPS dengan GAMIT/GLOBK 10.6

\begin{tabular}{cccc}
\hline \hline Stasiun & $\begin{array}{c}\text { Rata-Rata } \\
\text { Koordinat } \\
\text { Metode Jaring } \\
(\mathbf{m})\end{array}$ & $\begin{array}{c}\text { Rata-Rata } \\
\text { Koordinat } \\
\text { Metode Radial } \\
(\mathbf{m})\end{array}$ & Selisih $(\mathbf{m})$ \\
\hline DELS X & $-2211189,261$ & $-2211189,257$ & 0,004 \\
DELS Y & 5925224,163 & 5925224,177 & 0,014 \\
DELS Z & $-834607,604$ & $-834607,603$ & 0,001 \\
GRWH X & $-2210273,185$ & $-2210273,159$ & 0,026 \\
GRWH Y & 5926931,504 & 5926931,482 & 0,021 \\
GRWH Z & $-829623,368$ & $-829623,365$ & 0,004 \\
KLAT X & $-2208192,361$ & $-2208192,350$ & 0,010 \\
KLAT Y & 5927411,483 & 5927411,495 & 0,012 \\
KLAT Z & $-830792,319$ & $-830792,316$ & 0,003 \\
\hline \hline
\end{tabular}

\section{B. Analisa Outliers}

Outliers adalah data yang menyimpang terlalu jauh dari data lainnya dalam suatu rangkaian data. Adanya data outliers ini akan membuat analisa terhadap serangkaian data menjadi bias atau tidak mencerminkan fenomena yang sebenarnya. Pada perangkat lunak GAMIT/GLOBK deteksi outliers dapat dilihat pada data koordinat time series file Val.[expt] dalam folder gsoln. Deteksi data hari pengamatan yang ditandai sebagai outliers dengan melihat nilai weighted root mean square (wrms) plot time series setiap stasiun. Nilai wrms kurang dari 10 menandakan tidak adanya outliers [8]. Nilai wrms lebih besar dari 10 hanya terdapat pada stasiun DELS. Nilai wrms lebih dari 10 pada metode radial terdapat pada komponen north sebesar $13,7 \mathrm{~mm}$, east sebesar 48,6 mm, dan up sebesar $24,6 \mathrm{~mm}$ sedangkan pada metode jaring terdapat pada komponen up sebesar 14,2 mm. Pada gambar 4 terdapat data dengan nilai yang menyimpang dari data yang lainnya pada pengolahan radial GAMIT yaitu data pada doy 198 .

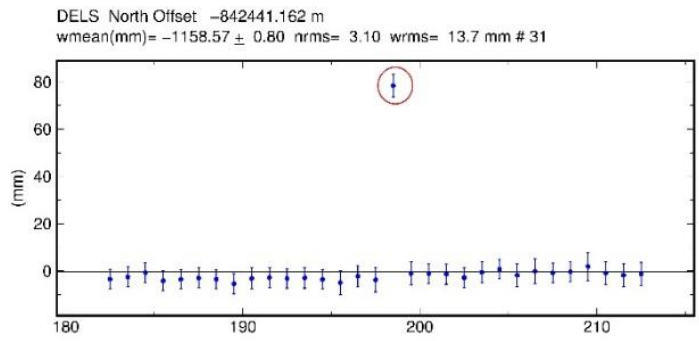

Gambar 4. Contoh plotting time series north stasiun DELS pengolahan radial GAMIT yang terdapat data outliers

Data pada doy-198 merupakan data yang tidak memenuhi evaluasi pengolahan GAMIT yaitu nilai fract diatas 10 . Penyebab data outliers ini kemungkinan disebabkan karena terhalangnya sinyal GPS untuk masuk ke antena GPS sehingga perekaman data yang diterima receiver GPS menjadi terganggu. Pada metode jaring tidak terlihat adanya loncatan koordinat karena data pengamatan double difference pada seluruh baseline saling mereduksi efek dari sebagian kesalahan dan bias. Dari indikator evaluasi pengolahan GAMIT dan nilai wrms dapat disimpulkan bahwa data pada doy-198 adalah data outliers. Data yang outliers atau tidak memenuhi kriteria dihilangkan menggunakan distribusi normal dengan selang kepercayaan $95 \%$ dengan faktor pengali 1,96 $\sigma$. Distribusi normal memiliki parameter distribusi yaitu rata-rata $($ mean $\mu)$ dan standar deviasi (standard deviation $\sigma$ ).

C. Analisa Perbandingan Standar Deviasi Metode Jaring dan Radial Hasil dari Perangkat Lunak GAMIT/GLOBK

Analisa standar deviasi digunakan untuk menentukan ratarata jarak penyimpangan titik-titik data diukur dari nilai ratarata data tersebut. Hasil pengolahan perangkat lunak GAMIT/GLOBK ditampilkan dalam plotting time series. Titik tengah (kotak) menandakan posisi koordinat tiap doy terhadap koordinat rata-rata. Sedangkan panjang garis menandakan besar standar deviasi hasil dari pengolahan perangkat lunak. Hasil perbandingan metode pengolahan data GPS ditampilkan dalam time series pada salah satu contoh gambar time series north dan east stasiun DELS di bawah ini.

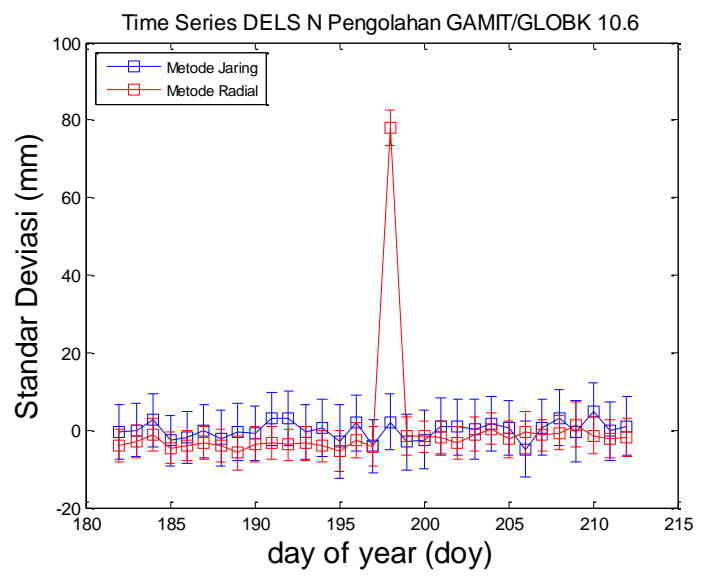

Gambar 5. Time series coordinate repeatabilities stasiun DELS - north

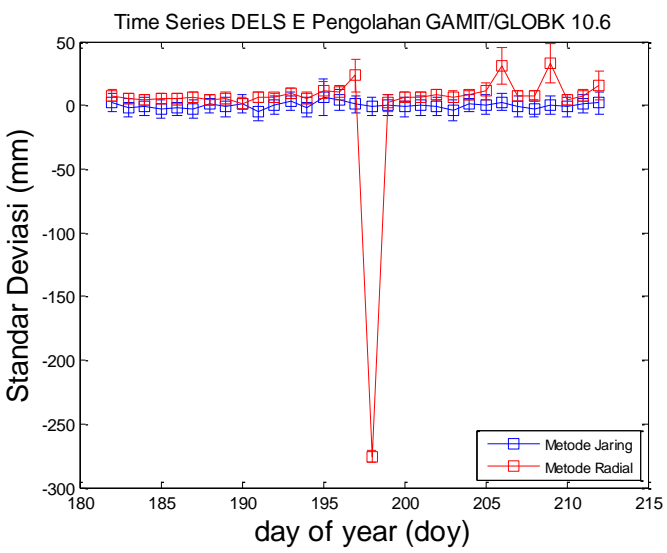

Gambar 6. Time series coordinate repeatabilities stasiun DELS - east

Pada gambar 5 komponen north stasiun DELS, rata rata standar deviasi yang dihasilkan perangkat lunak GAMIT perdoy pada metode jaring adalah $7,2 \mathrm{~mm}$ lebih besar daripada metode radial yaitu 4,4 $\mathrm{mm}$. Sedangkan pada komponen east stasiun DELS, rata rata standar deviasi yang dihasilkan perangkat lunak GAMIT per-doy pada metode jaring adalah 7,7 $\mathrm{mm}$, lebih besar daripada metode radial yaitu $5,7 \mathrm{~mm}$. Pada metode radial terdapat nilai outliers pada pengolahan radial GAMIT doy-198 yang berakibat standar deviasi titik pengamatan menjadi lebih besar. Tetapi pada metode jaring tidak terlihat adanya loncatan koordinat karena data pengamatan double difference pada seluruh baseline saling 
mereduksi efek dari sebagian kesalahan dan bias yang menyebabkan standar deviasi/doy pada metode jaring lebih besar daripada radial. Data outliers ini harus dihilangkan agar tidak mempengaruhi ketelitian hasil data yang diperoleh. Sedangkan pada stasiun lain yaitu GRWH dan KLAT standar deviasi/doy relatif pada metode jaring lebih kecil daripada metode radial.

Secara keseluruhan hasil pengolahan data GPS CORS dengan GAMIT dapat disimpulkan koordinat yang dihasilkan presisi mendekati rata-rata dan mempunyai nilai standar deviasi yang kecil (orde milimeter). Hal ini dikarenakan pada pengolahan GAMIT dapat mengestimasi efek dari kesalahan dan bias yang didukung oleh beberapa data sekunder seperti file atmosfer, gelombang pasang surut dan pemodelan cuaca.

\section{Analisa Perbandingan Standar Deviasi Titik Pengamatan Stasiun GPS CORS Merapi}

Standar deviasi adalah akar kuadrat dari variansi dan menunjukkan standar penyimpangan data terhadap nilai rataratanya. Parameter standar deviasi yang dihasilkan dari perangkat lunak GAMIT/GLOBK adalah koordinat lokal north, east, up. Koordinat lokal ini merupakan hasil transformasi koordinat dari koordinat geosentrik dengan coding matlab. Hasil dari standar deviasi titik pengamatan stasiun GPS CORS Merapi dengan metode jaring dan radial ditampilkan pada tabel 5 sebagai berikut.

Tabel 5.

Standar deviasi titik pengamatan stasiun GPS CORS Merapi

\begin{tabular}{ccc}
\hline \hline Stasiun & $\begin{array}{c}\text { Jaring (m) } \\
\text { GAMIT } \\
\text { GLOBK }\end{array}$ & $\begin{array}{c}\text { Radial (m) } \\
\text { GAMIT } \\
\text { GLOBK }\end{array}$ \\
\hline DELS N & 0,00220 & 0,01433 \\
DELS E & 0,00237 & 0,05080 \\
DELS U & 0,01411 & 0,02757 \\
GRWH N & 0,00162 & 0,00290 \\
GRWH E & 0,00205 & 0,00362 \\
GRWH U & 0,00079 & 0,00147 \\
KLAT N & 0,00132 & 0,00204 \\
KLAT E & 0,00104 & 0,00397 \\
KLAT U & 0,00058 & 0,00100 \\
\hline \hline
\end{tabular}

Pada tabel 5 dapat diketahui bahwa standar deviasi paling kecil dihasilkan dari metode jaring menggunakan perangkat lunak GAMIT/GLOBK menghasilkan orde sampai milimeter. Pada stasiun DELS (north, east, up) pengolahan data GPS menggunakan GAMIT/GLOBK metode radial mempunyai standar deviasi paling besar. Hal ini akibat pengaruh dari adanya data yang menyimpang terlalu jauh (outliers) pada doy ke-198. Adanya outliers sangat berpengaruh terhadap nilai dari standar deviasi yang dihasilkan. Jika nilai outliers tersebut dihilangkan maka standar deviasi yang dihasilkan ditampilkan pada gambar 9 sebagai berikut.

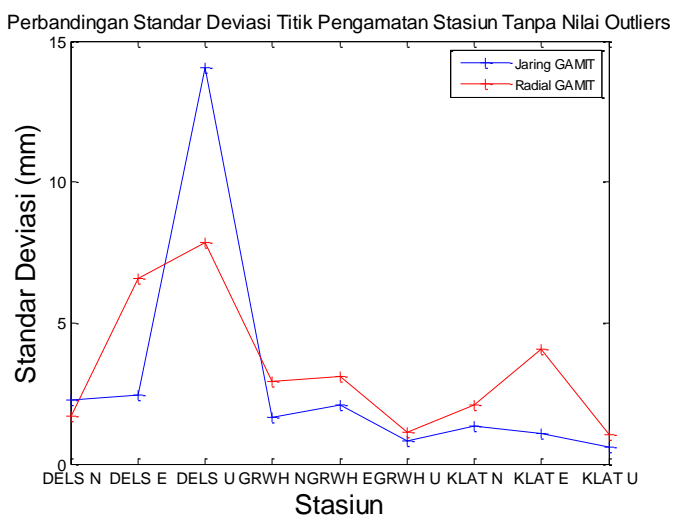

Gambar 7. Grafik perbandingan standar deviasi titik pengamatan stasiun tanpa nilai outliers

Pada gambar 7 dapat diketahui metode jaring menggunakan perangkat lunak baik GAMIT/GLOBK menghasilkan standar deviasi yang lebih kecil daripada metode radial. Hal ini dikarenakan pada metode jaring geometri untuk penentuan posisi relatif lebih kuat daripada metode radial yang berpengaruh pada ketelitian posisi yang diperoleh [5].

\section{E. Uji Statistik}

Pada uji statistik ini dilakukan dengan membandingkan variansi dari kedua pengolahan, pada uji ini dilakukan dengan menggunakan rumus [4]:

$$
F=\frac{s_{1}^{2}}{s_{2}^{2}} \text { atau } F=\frac{s_{2}^{2}}{s_{1}^{2}} F=\frac{\text { large sample variance }}{\text { small sample variance }}
$$

Uji Statistik yang digunakan untuk menentukan penolakan dari hipotesis nol.

$$
F_{\propto / 2, v 1, v 2}=\frac{1}{F_{1-\alpha, v 2, v 1}}
$$

Hipotesa nol yang digunakan pada uji statistik ini adalah metode pengolahan tidak terdapat perbedaan yang signifikan, sehingga:

Hipotesa nol $\quad \mathrm{H} 0: \mathrm{dV}=0$

Hipotesa alternatif $\quad \mathrm{H} 0: \mathrm{dV} \neq 0$

Apabila dari uji hipotesis 0 menunjukkan $\mathrm{F}$ hitung $<\mathrm{F}$ tabel, maka tidak terdapat perbedaan ketelitian yang signifikan. Sebaliknya apabila dari uji hipotesis alternatif menujukan $\mathrm{F}$ hitung > F tabel, maka terdapat perbedaan ketelitian yang signifikan.

Adapun hasil dari hitung nilai rata-rata standar deviasi dan variansi tanpa mengikut-sertakan data outliers dapat dilihat pada tabel 6 di bawah ini.

Tabel 6.

Hasil hitungan rata-rata standar deviasi dan variansi

\begin{tabular}{ccccc}
\hline \hline No. & Metode & $\begin{array}{c}\text { Rata- } \\
\text { Rata } \\
(\mathbf{m})\end{array}$ & $\begin{array}{c}\text { Variansi } \\
\left(\mathbf{m}^{\mathbf{2}}\right)\end{array}$ & Keterangan \\
\hline $\mathbf{1}$ & Jaring & 0,00292 & 0,00000853 & setelah remove outliers \\
$\mathbf{2}$ & Radial & 0,00339 & 0,00001147 & setelah remove outliers \\
$\mathbf{3}$ & Jaring & 0,00290 & 0,00000841 & sebelum remove outliers \\
$\mathbf{4}$ & Radial & 0,01197 & 0,00014319 & sebelum remove outliers \\
\hline \hline
\end{tabular}

Pada uji statistik ini dihitung dan dianalisa menggunakan selang kepercayaan 95\% dan derajat kebebasan 30. Maka

$$
\begin{aligned}
& 1-\alpha=1-0.95=0.05 \\
& F_{\propto / 2, v 1, v 2}=F_{0.025,30,30}=2.07
\end{aligned}
$$


Pada tabel distribusi F, diperoleh nilai 2,07. Apabila F hitung $<2,07$ maka hasil uji yang diperoleh adalah tidak signifikan, sebaliknya jika F hitung > 2,07 maka hasil uji yang diperoleh adalah signifikan. Hasil uji statistik yang diperoleh dapat dilihat pada tabel 7 di bawah ini.

Tabel 7.

Hasil hitungan uji statistik perbandingan 2 perangkat lunak dan 2 metode

\begin{tabular}{|c|c|c|c|c|c|}
\hline \multicolumn{2}{|c|}{ Pengolahan } & $\begin{array}{c}\mathrm{F} \\
\text { Hitung }\end{array}$ & $\begin{array}{c}\text { F } \\
\text { Tabel }\end{array}$ & Hasil Uji & Keterangan \\
\hline $\begin{array}{l}\text { Jaring } \\
\text { GAMIT }\end{array}$ & $\begin{array}{c}\text { Radial } \\
\text { GAMIT }\end{array}$ & 1,35 & & $\begin{array}{c}\text { Tidak } \\
\text { signifikan }\end{array}$ & $\begin{array}{l}\text { Setelah } \\
\text { remove } \\
\text { outliers }\end{array}$ \\
\hline $\begin{array}{c}\text { Jaring } \\
\text { sebelum } \\
\text { remove } \\
\text { outliers } \\
\text { Radial } \\
\text { sebelum } \\
\text { remove } \\
\text { outliers }\end{array}$ & $\begin{array}{l}\text { Jaring } \\
\text { setelah } \\
\text { remove } \\
\text { outliers } \\
\text { Radial } \\
\text { setelah } \\
\text { remove } \\
\text { outliers }\end{array}$ & 12,48 & 2,07 & $\begin{array}{c}\text { Tidak } \\
\text { signifikan }\end{array}$ & $\begin{array}{c}\text { Perbandingan } \\
\text { sebelum dan } \\
\text { sesudah } \\
\text { remove } \\
\text { outliers }\end{array}$ \\
\hline
\end{tabular}

Pada tabel 7 dapat diketahui pengolahan radial GAMIT terdapat perbedaan ketelitian secara signifikan. Hal ini dipengaruhi oleh adanya outliers yang terdeteksi di stasiun DELS pada doy-198. Salah satu indikator adanya outliers adalah nilai wrms yang lebih dari 10 [10]. Pada doy-198 pengolahan radial GAMIT juga tidak memenuhi evaluasi hasil pengolahan GAMIT yang ditetapkan yaitu nilai fract harus lebih kecil dari 10. Nilai fract di atas 10 mengindikasikan ada kesalahan kasar dan sistematik pada proses pengolahan tersebut [7]. Data yang terindikasi outliers harus dihilangkan agar hasil tidak menjadi bias.

Rata-rata nilai standar deviasi hasil pengolahan dengan menggunakan perangkat lunak GAMIT/GLOBK 10.6 adalah $3,2 \mathrm{~mm}$. Perangkat lunak GAMIT/GLOBK memberikan tingkat hasil pengolahan data yang presisi mencapai orde sampai milimeter. Perangkat lunak ilmiah mempunyai kelebihan dalam model matematik yang lebih lengkap dimana parameterparamater yang berpengaruh kecil dimasukkan dalam perhitungan sehingga perangkat lunak ilmiah sangat direkomendasikan untuk pengolahan data GPS yang memerlukan ketelitian tinggi (sampai orde milimeter).

Sedangkan antara metode jaring dan radial tidak terdapat perbedaan ketelitian yang signifikan. Pada pengolahan GAMIT/GLOBK selisih standar deviasi antara metode jaring dan radial adalah 0,47 . Selisih rata-rata standar deviasi metode jaring dan radial tidak jauh berbeda yaitu di bawah 1 milimeter. Perbedaan yang tidak signifikan tersebut disebabkan karena data yang digunakan adalah data GPS CORS yang secara kontinyu sudah memberikan tingkat presisi yang tinggi. Hal ini juga didukung oleh semakin berkembangnya teknologi receiver, perangkat lunak pengolahan data GPS, serta semakin banyaknya jumlah satelit, ketelitian posisi dengan menggunakan metode radial mungkin akan menyamai ketelitian dengan metode jaring tertutup [9] .

\section{KESIMPULAN}

Berdasarkan hasil analisa tugas akhir yang telah dilakukan maka dapat diambil kesimpulan sebagai berikut:

1.Pengolahan data GPS CORS Gunung Merapi dengan GAMIT/GLOBK 10.6 memberikan tingkat hasil pengolahan data yang presisi sampai orde milimeter.

2.Rata-rata nilai standar deviasi hasil pengolahan dengan menggunakan perangkat lunak GAMIT/GLOBK metode jaring tertutup adalah $2,92 \mathrm{~mm}$ sedangkan pada metode radial adalah 3,39 mm.

3.Dari uji statistik, ketelitian yang dihasilkan dari pengolahan data GPS CORS Gunung Merapi menggunakan konfigurasi jaring tertutup dan radial tidak terdapat perbedaan yang signifikan. Selisih rata-rata standar deviasi pada pengolahan GAMIT/GLOBK antara metode jaring dan radial adalah 0,47 $\mathrm{mm}$.

\section{UCAPAN TERIMA KASIH}

Penulis A.A.R. mengucapkan terima kasih kepada Balai Penyelidikan dan Pengembangan Teknologi Kebencanaan Geologi (BPPTKG) Yogyakarta yang telah memberikan izin untuk melakukan penelitian dan Ibu Sulistiyani sebagai pembimbing.

\section{DAFTAR PUSTAKA}

[1] Badan Penyelidikan dan Pengembangan Teknologi Kebencanaan Geologi. 2014. Karakteristik Gunung Merapi. <url: http://www.merapi.bgl.esdm.go.id >. Dikunjungi pada 20 Maret 2016, Jam $09.00 \mathrm{WIB}$.

[2] Abidin, H.Z. 2007. Penentuan Posisi dengan GPS dan Aplikasinya. Jakarta: PT Pradnya Paramita.

[3] Hofman-Wellenhof, B., Lichtenegger, H., dan Collins, J. 2000. GPS Theory and Practice. Austria: Springer-Verlag Wien New York.

[4] Wolf, P. R., dan Ghilani, C. D. 2006. Adjustment Computations Spatial Data Analysis. New Jersey: John Willey \& Sons Inc.

[5] Abidin, H. Z., Jones, A., dan Kahar, J. 2011. Survei Dengan GPS. Cetakan Ketiga. Jakarta: PT Pradnya Paramita.

[6] Herring, T. A., King, R.W., Floyd, M.A., dan McClusky, S.C. 2015. GAMIT Reference Manual Release 10.6. Massachusetts: Departement of Earth, Atmospheric, and Planetary Sciences Massachusetts Institute of Technology.

[7] Artini, S. R. 2014. "Penentuan Koordinat Stasiun GNSS CORS GMU1 dengan Kombinasi Titik Ikat GPS Global dan Regional". Jurnal Teknik Sipil, 37-44.

[8] Herring, T. A., King, R.W., Floyd, M.A., dan McClusky, S.C. 2015. GLOBK Reference Manual Release 10.6. Massachusetts: Departement of Earth, Atmospheric, and Planetary Sciences Massachusetts Institute of Technology.

[9] Nathania, Clara. 2013. Kajian Pengaruh Penggunaan Metode Survei GPS Jaring Tertutup dan Radial Terhadap Ketelitian Posisi. Tugas Akhir Program Studi Teknik Geodesi dan Geomatika ITB.

[10] Kaniuth, K., dan Volksen, C. "Comparison of the Bernese and Gipsy/Oasis II Software Systems Using EUREF Data". 314-319. 